\title{
Bio-Fuel Properties and Elemental Analysis of Bio-Oil Produced from Pyrolysis of Gmelina Arborea
}

\author{
Adegoke Idowu $A^{\mathrm{a} *}$., Ogunsanwo 0.Y ${ }^{\mathrm{b}}$ and Ige Ayodeji Rc. \\ a Department of Forestry and Wildlife Management, Federal University Gashua, Yobe State, Nigeria. \\ b Department of Forest Products and Production, University of Ibadan, Oyo State, Nigeria. \\ c Department of Pure and Applied Chemistry, Kebbi State University of Science and Technology, Aliero, Nigeria. \\ *Corresponding Author Email: adegokeabimbola4u@yahoo.com; igeayodeji2@gmail.com
}

\section{DOI: 10.2478/acmy-2021-0006}

\section{Abstract:}

Nigeria demand for sustainable, affordable and accessible energy is on the rise. Hence, this led to rigorous research to determine affordable processes of using waste materials for production of sustainable energy. In this research pyrolysis was carried out in a fabricated fixed bed pilot-scale reactor using Gmelina arborea (sawdust) biomass for the production of bio-oil. The physical, chemical properties and the ultimate analysis of the bio oil produced were determined following standard methods. The physicochemical properties and ultimate analysis obtained were favourable. The highest moisture content of $21 \%$ at $600{ }^{\circ} \mathrm{C}$ and least moisture content of $12 \%$ at $900{ }^{\circ} \mathrm{C}$ were obtained from Gmelina arborea. The elemental results of the products show low sulphur quantity which is of good prospects that Gmelina arborea are good materials for bioenergy production without posing danger to the environment. Utilisation of Gmelina arborea for bio-oil production as an alternative fuel would shun unfavourable environmental abasement related to the use of conventional fuels.

Keywords: Pyrolysis, Gmelina arborea, bio-oil, Reactor, physicochemical properties

\subsection{Introduction:}

Biomass is a significant storehouse of renewable carbon and has enormous potentials for supplying renewable energy. Lignocellulosic biomass comprises of agricultural residues, dedicated energy crops, and forest residues. Unlike food grains, sugar-or starch-based crops, and oil seeds, lignocellulosic feedstocks are inexpensive, available abundantly [1]. Biomass is also complex biological organic or non-organic solid product derived from living or recently living organism and available naturally [2]. Biomass is one of the most promising sources of alternative energy which can solve the problem of energy crisis in world up to some extent due to its potential availability. Besides, the use of biomass can also reduce the problem of global warming and pollution [2]. It is of three products which are solid fuel, liquid fuel and gases. Pyrolysis is believed to be one of the most promising thermo-chemical technologies with the potential to convert cheap, local, and abundant lignocellulosic biomass such as grasses and trees into a useful form [3], [4]. Pyrolysis of biomass can be described as the direct thermal decomposition of the organic matrix in the absence of oxygen to obtain an array of solid, liquid and gas products. The pyrolysis method has been used for commercial production of a wide range of fuels, solvents, chemicals and other products from biomass feedstocks [5]. For instance, materials such as tropical woody biomass [6], palm fruit fibre [7]; others like, rice husk [8], groundnut shell [9] and many more are also used as energy sources via pyrolysis.

Pyrolysis process can be classified as fast and slow pyrolysis. Slow pyrolysis produces relatively more biochar but less bio-oil with about $35 \%$ of the feedstock carbon ending up as biochar, $30 \%$ as bio-oil and 35\% as condensable gases [10]. Fast pyrolysis gives $15 \%$ biochar yield, $70 \%$ bio-oil and $13 \%$ condensable gases [11]. The yields of the pyrolysis products depend on the various variables including, temperature, particle size, residence time, reactor configuration, heating rate etc. [12], [13]. The importance of sawdust as a source of fuel cannot be overstated as it is willingly available and economical [14]. The selection of Gmelina arborea sawdust for this research is due to its current utilization pattern which makes the waste to be abundantly available in most wood processing mills [15]. Ogunsanwo and Adegoke [15], reported that the utilization of sawdust for bio oil production is a promising way of harnessing large quantity of forest waste which is currently vastly under-utilized. The preliminary study on the utilization of some selected species for the production of bio oil necessitate further research into its utilization in terms of chemical properties, hence the characterization of bio-oil from Gmelina arborea wood species which is of high importance for proper use and classification.

\subsection{Materials and Methods}

\subsection{Sample Collection}

Gmelina arborea sawdust was collected from Forestry Research Institute of Nigeria Sawmill, located at Jericho Ibadan, Oyo State, Nigeria. The sawmill is one of the major mills where G. arborea is mainly processed.

\subsection{Sample Preparation}

The sawdust sample was pulverized and rinsed with tap water to remove impurities and were dried in the oven at $105^{\circ} \mathrm{C}$ for $24 \mathrm{hr}$. The dried pulverized biomass was stored in air-tight containers until further use [16]. Prior pyrolysis at each temperature regimes $\left(600^{\circ} \mathrm{C}, 650^{\circ} \mathrm{C}, 700^{\circ} \mathrm{C}, 750^{\circ} \mathrm{C}, 800^{\circ} \mathrm{C}, 850^{\circ} \mathrm{C}\right.$ and $900^{\circ} \mathrm{C}$ ). Six replicates of bio-oil were produced at each temperature regime. The data generated were subjected to Analysis of Variance (ANOVA) in Completely Randomized Design. Least Significant Difference (LSD) was used as a follow up test for the relationship that is significant at 5\% level of probability. Fabricated Pyrolytic chamber was use (Figure 1) for the extraction of the sawdust sample. The reactor was made from stainless steel plate to prevent rusting, also connected to a glassware condenser for condensation process with reactor fixed stock capacity of $1 \mathrm{Kg}$ and electrical heater capacity $1 \mathrm{Kw} .1 \mathrm{Kg}$ of the sawdust sample were filled into the reactor which was connected to a condenser. The evolving gases were distilled in the condenser to form bio-oil and were collected inside a conical flask. The fabricated fixed bed reactor is without the solid catalyst particles being loaded. This is to determine the efficiency of the reactor and effects of temperature at different regimes on the quality of bio-oil produced without using catalyst and also to save cost.

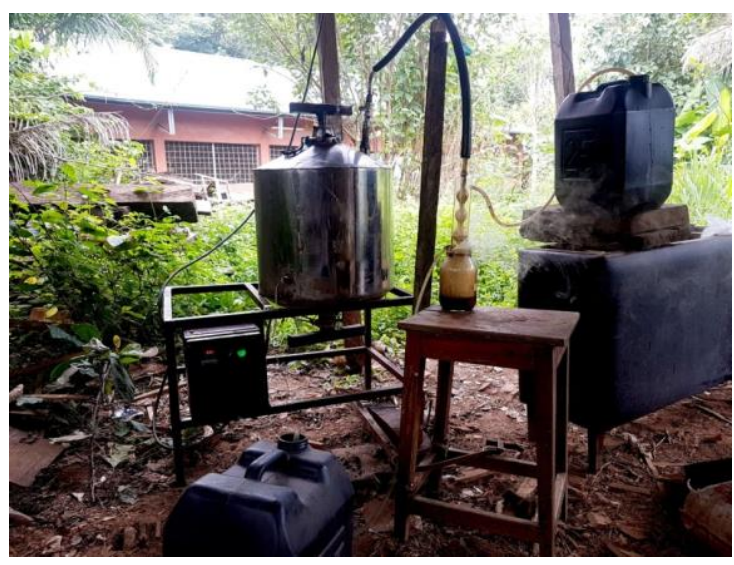

Figure 1. Fabricated Pyrolysis Reactor Set-up 
2.3. pH Determination

In order to evaluate the corrosive property of the bio-oil products, the $\mathrm{pH}$ of the bio-oil was measured using a pH meter from Eutech Instruments, type of $\mathrm{pH}$ tutor which has an electrode that was calibrated with two buffer solutions. The electrode was directly dipped into the bio-oil sample. The sample size of bio-oil was 1-2 $\mathrm{ml}$. The recorded value is the final result, expressed as a $\mathrm{pH}$ of bio-oil.

\subsection{Density Determination of bio-oil from Gmelina arborea ASTM D 4052, (1988)}

The density of a material is defined as mass per unit volume of sample and this was determined according to [17] using digital density analyzer. Firstly, the density meter was calibrated by water at $25^{\circ} \mathrm{C}$ before measurement in order to minimize the errors. Then, $1 \mathrm{ml}$ of bio-oil was injected into the density meter at $25^{\circ} \mathrm{C}$ and repeated three times. The average value is the final result, expressed as density in $\mathrm{g} / \mathrm{cm}^{3}$.

\subsection{Kinematic Viscosity Determination ASTM D 445 (1988)}

Kinematic viscosity is a measure of the resistance to gravity flow of a fluid. Viscosity of a liquid is an important property since it affects the flow of the liquid through pipelines. The viscosity was measured with a Cannon-Fenske up-flow viscometer. A sample (20 ml) of each of the bio-oils was placed in the viscometer and the flow was observed at $40^{\circ} \mathrm{C}[18]$.

\subsection{Ash Content (ASTM-D 482-07)}

Ash is the incombustible material, which remains when fuel is burned. Ash is detrimental in combustion processes as it lowers the calorific value of the fuel. Excessive amounts of ash can cause high wear in pumps and injectors and lead to deposits in combustion equipment. The bio oil sample was contained in a suitable vessel which was ignited and allowed to burn until only ash and is carbon remained. The carbonaceous residue was reduced to an ash by heating in a furnace at $600^{\circ} \mathrm{C}$ with a heating time of $1 \mathrm{hour}$, followed by cooling inside desiccator and weighed [29].

The mass of the ash was calculated as a percentage of the original samples as followed:

Ash, $\operatorname{mass} \%=(\mathrm{w} / \mathrm{W}) \times 100$

where:

$\mathrm{w}=$ mass of ash $(\mathrm{g})$

$\mathrm{W}=$ mass of sample $(\mathrm{g})$

\subsection{Volatile Matter}

The fixed carbon contents were calculated by difference between the percentage ash content and the percentage volatile matter [20].

\subsection{Moisture Content ASTM D 1744 (1988)}

The moisture content of the bio-oil was determined using Karl Fischer Titrator, type 784 KFP Titrino, Metrohm based on ASTM D 1744. The bio-oil was titrated with standard Karl Fischer reagent to an electrometric end point [21].

\subsection{Elemental Analysis of Bio-0il produced from Gmelina arborea}

The purpose of this test is to determine element percent of carbon, hydrogen, nitrogen and oxygen in the bio oil samples to know their relativity to that of physicochemical properties of the bio-oil samples towards upgrading purposes. The elemental analysis was determined using an Elemental Analyser, Euro EA 3000 using Callidus Software Interface Version 4.1. The main components of Elemental Analyzer consist of quartz tube reactor (packed CHNS kits), column, gas chromatography oven, front furnace (temperature maximum $1020^{\circ} \mathrm{C}$ ) the detecting system used thermal conductivity detector and oxygen trap [20].

\subsection{Results}

Table 1: Physicochemical analysis of bio-oil produced from sawdust of Gmelina arborea

\begin{tabular}{lllllll}
$\begin{array}{l}\text { Temperature } \\
\text { Range }\left({ }^{\circ} \mathrm{C}\right)\end{array}$ & $\mathbf{p H}$ & $\begin{array}{l}\text { Moisture } \\
\text { Content \% }\end{array}$ & $\begin{array}{l}\text { Density } \\
\mathrm{g} / \mathrm{cm}^{3}\end{array}$ & $\begin{array}{l}\text { Kinematic } \\
\text { Viscosity (cst) }\end{array}$ & Ash Content \% & $\begin{array}{l}\text { Volatile } \\
\text { \% }\end{array}$ \\
\hline 600 & $3.65 \pm 0.008^{\mathrm{c}}$ & $21.00 \pm 0.000^{\mathrm{a}}$ & $1.03 \pm 0.000^{\mathrm{b}}$ & $14.00 \pm 0.000^{\mathrm{e}}$ & $0.23 \pm 0.002^{\mathrm{f}}$ & $77.44 \pm 0.005^{\mathrm{a}}$ \\
650 & $3.93 \pm 0.063^{\mathrm{a}}$ & $22.00 \pm 0.000^{\mathrm{b}}$ & $1.02 \pm 0.000^{\mathrm{b}}$ & $19.00 \pm 0.000^{\mathrm{c}}$ & $0.79 \pm 0.002^{\mathrm{c}}$ & $52.76 \pm 0.002^{\mathrm{b}}$ \\
700 & $3.73 \pm 0.023^{\mathrm{b}}$ & $20.00 \pm 0.000^{\mathrm{c}}$ & $1.13 \pm 0.000^{\mathrm{a}}$ & $16.50 \pm 0.000^{\mathrm{d}}$ & $2.28 \pm 0.002^{\mathrm{a}}$ & $27.56 \pm 0.003^{\mathrm{e}}$ \\
750 & $3.75 \pm 0.004^{\mathrm{b}}$ & $18.00 \pm 0.000^{\mathrm{d}}$ & $1.13 \pm 0.000^{\mathrm{a}}$ & $19.00 \pm 0.000^{\mathrm{c}}$ & $0.08 \pm 0.003^{\mathrm{b}}$ & $40.06 \pm 7.502^{\mathrm{c}}$ \\
800 & $3.50 \pm 0.004^{\mathrm{d}}$ & $16.00 \pm 0.000^{\mathrm{e}}$ & $1.11 \pm 0.000^{\mathrm{a}}$ & $20.00 \pm 0.000^{\mathrm{b}}$ & $0.28 \pm 0.002^{\mathrm{e}}$ & $29.20 \pm 1.014^{\mathrm{d}}$ \\
850 & $3.11 \pm 0.012^{\mathrm{f}}$ & $14.00 \pm 0.000^{\mathrm{f}}$ & $1.03 \pm 0.000^{\mathrm{b}}$ & $24.00 \pm 0.000^{\mathrm{a}}$ & $0.15 \pm 0.002^{\mathrm{g}}$ & $29.69 \pm 1.433^{\mathrm{d}}$ \\
900 & $3.46 \pm 0.008^{\mathrm{e}}$ & $12.00 \pm 0.000^{\mathrm{g}}$ & $1.03 \pm 0.000^{\mathrm{b}}$ & $24.50 \pm 0.000^{\mathrm{a}}$ & $0.52 \pm 0.02^{\mathrm{d}}$ & $30.88 \pm 1.874^{\mathrm{d}}$ \\
\hline
\end{tabular}

Mean with the same superscript alphabet in a column are not significantly different at $5 \%$ probability level; \pm standard deviation

Table 2: Elemental components of Bio oil

\begin{tabular}{|c|c|c|c|c|c|c|c|}
\hline \multirow{2}{*}{$\begin{array}{l}\text { Parameter } \\
\text { (\%) }\end{array}$} & \multicolumn{7}{|c|}{ Temperature regimes $\left({ }^{\circ} \mathrm{C}\right)$} \\
\hline & 600 & 650 & 700 & 750 & 800 & 850 & 900 \\
\hline Carbon & 50.70 & 51.16 & 51.23 & 52.33 & 52.63 & 54.70 & 58.92 \\
\hline Hydrogen & 1.54 & 1.39 & 1.96 & 2.26 & 0.20 & 0.46 & 0.20 \\
\hline Nitrogen & 0.02 & 0.04 & 0.18 & 0.22 & 0.31 & 0.37 & 0.28 \\
\hline Sulphur & 0.02 & 0.1 & 0 & 0 & 0 & 0 & 0 \\
\hline Oxygen & 47.48 & 47.25 & 46.57 & 45.13 & 46.82 & 44.23 & 40.56 \\
\hline
\end{tabular}

\subsection{Discussion}

The bio oil exhibits a low $\mathrm{pH}$ value and they are therefore, corrosive. The $\mathrm{pH}$ of the bio-oil increased with rise in pyrolysis temperature and later decreased at $800^{\circ} \mathrm{C}$. The least and highest $\mathrm{pH}$ value of the bio-oils from Gmelina arborea varied between 3.13 and 3.95. The finding is in agreement with $\mathrm{pH}$ of bio-oil produced from corn stover (3.0), big bluestem (3.4) and Praire cord grass (3.6) respectively [22]. Whereby, Yu et al [23] reported a lower pH of 2.87 for the bio-oil produced from corn stover through MAP. Bio-oil generally contained substantial amount of organic acids, mostly acetic acid and formic acids, which give the bio-oil its low $\mathrm{pH}(2-3)$ [24]. Acids with water are the main reason for the corrosiveness of pyrolysis bio-oils, especially at elevated temperatures [25]. The result of the percentage moisture content is presented in table 1. which revealed that percentage moisture content of the bio oil produced from Gmelina arborea sawdust which decreases as the pyrolysis temperature increases. Bio-oils produced at $600^{\circ} \mathrm{C}$ had highest moisture content of $25.00 \% \mathrm{wt}$ while bio oil obtained at $900^{\circ} \mathrm{C}$ had the least moisture content of $13.00 \% w t$. It is also in agreement with many reported results of [26] and also compare well to the palm shell bio-oil [27]. The moisture content (water) that is produced in the pyrolysis reaction together with any water contained from the biomass feedstock. The amount of water in the product depends on the process parameters including the extent of secondary reaction or cracking and the temperature of the product gases leaving the liquid collection system. With regard to the combustion applications of bio-oil, the most relevant feature in 
the bio-oil composition is the high-water content, which has both positive and negative effects on its applications.

The high-water content of the bio-oil contributes to their low energy density, lowers the adiabatic flame temperature and local combustion temperatures as well as lowers the combustion reaction rates due to its relatively high vaporisation temperature and high specific heat in the vapour phase. The result of the density presented in table 1 revealed that there is significant difference in the values obtained at different temperature regimes, with bio oil produced at $700^{\circ} \mathrm{C}$ to $750^{\circ} \mathrm{C}$ having the highest density value of $1.15 \mathrm{~g} / \mathrm{cm}^{3}$. Abdullah and Gerhauser [28] described bio-oil as a highly dense liquid with a density around $1.2 \mathrm{gcm}^{-3}$, which is in agreement with the values of density obtained for the samples. Piyarat and Chaiyot, [29] reported $1.18 \mathrm{~g} / \mathrm{cm}^{3} \mathrm{and} 1.10 \mathrm{~g} / \mathrm{cm}^{3} \mathrm{as}$ the density of palm shell bio-oil and cassava pulp residue and are compare well with the results obtained. Density is a fundamental physical property that can be used in conjunction with other properties to characterise bio-oil products. The characteristics of the bio-oils derived from Gmelina arborea sawdust at the seven temperature regimes based on the physico-chemical properties assessed were very similar to the characteristics of other biomass pyrolytic oils. Kinematic viscosity was observed at $40^{\circ} \mathrm{C}$ for the bio oil produced from Gmelina arborea sawdust for each of the seven temperature regimes $600^{\circ} \mathrm{C}$ $650^{\circ} \mathrm{C}, 700^{\circ} \mathrm{C}, 750^{\circ} \mathrm{C}, 800^{\circ} \mathrm{C}, 850^{\circ} \mathrm{C}$ and $900^{\circ} \mathrm{C}$ respectively (Table 1). Further analysis of bio-oil (produced at $750^{\circ} \mathrm{C}$ ) showed that its viscosity increased as the temperature increased.

The high viscosity value of bio oil from Gmelina arborea sawdust will inhibit free flow of the bio oil. Viscosity is a property that represents the flow characteristics of the fuel. High viscosity in a fuel, leads to several problems such as incomplete combustion, formation of deposits at the tip of injection nozzles and contamination of lubricating oils [30]. The values shown above suggest that, the bio-oil under study requires upgrading in order to conform to recommended specification with respect to kinematic viscosity. To overcome this viscosity problem, hydrodeoxygenation reaction is one the possible upgrading method i.e., by partial or total elimination of oxygen and hydrogenation of chemical structures. For all the temperature regimes bio oil produced from $700^{\circ} \mathrm{C}$ has the highest mean percentage ash content while bio oil produced from $850^{\circ} \mathrm{C}$ has the least mean percentage ash content. The percentage ash content and volatile matter were the required prerequisite for the determination of heating value of the samples. It was observed that there is significant difference in the percentage ash content and volatile matter at different temperature regimes used. Ash is an impurity that will not burn which reduces handling and burning capacity, it increases handling cost and affects combustion efficiency causes clinkering and slagging. Excessive ash in fuel can cause fouling deposits in the combustion equipment. Ash is the incombustible material, which remains when fuel is burned. Ash is detrimental in combustion processes in which it lowers the calorific value of the fuel. Excessive amounts of ash can cause high wear in pumps and injectors and lead to deposits in combustion equipment while high volatile matter content indicates easy ignition of fuel [15].

After pyrolysis the volatile matter content of the bio oil from Gmelina arborea reduces between the different temperatures regimes with bio oil produced at $700^{\circ} \mathrm{C}$ having the highest mean percentage ash content of $2.30 \%$, while bio oil produced at $600^{\circ} \mathrm{C}$ had the least mean percentage ash content which indicates higher biomass to liquid fuels from this species. As a result of decrease in volatile matter content from $97.44 \%$ at temperature of $600^{\circ} \mathrm{C}$ to $31.88 \%$ at temperature of $900^{\circ} \mathrm{C}$, fixed carbon of the samples increases significantly which means there is less liberation of fixed carbon and this may be due to its chemical composition and presence of high extraneous materials. The elemental analysis of oil is an important criterion for the design of a combustion plant utilizing the oil. The ultimate analysis showed the variations in the elemental composition of bio oil produced from sawdust of Gmelina arborea at different temperature regimes (Table 2). The analysis showed significant variation in carbon and oxygen content whereas there were slight variations in hydrogen, nitrogen and sulphur content. Some of the oxygen in the original feedstock has turned into $\mathrm{H}_{2} \mathrm{O}, \mathrm{CO}$ and $\mathrm{CO}_{2}$. The results obtained are in contrary to the results of ultimate analysis of Municipal Solid Waste reported by Rahman et al., [31] in which the carbon decreasing as the temperature increases while they are in same range of values with the carbon, oxygen, nitrogen. With the quantity of the sulphur show it is very glaring that it will not pose more dangers into the environment [32]. It was observed that changing the temperature causes a slight change in the elemental content of the bio-oil samples. However, no particular trends in the elemental composition were found within the range of reaction temperatures used.

\subsection{Conclusion}

The physicochemical properties of the bio-oil obtained from Gmelina arborea, fall within the acceptable range for bio-oil production. The ultimate analysis showed the minimal sulphur content. The selected wood specie is therefore suitable for production of bio-oil with acceptable physical and chemical properties. With the results obtained in this research Gmelina arborea shows good fuel potentials with less hazardous characteristics most especially in Nigeria where there is abundance availability of it for mass production.

\subsection{Competing Interests}

The authors declare that they have no competing interests on the research.

\subsection{Authors Contributions}

Adegoke Idowu Abimbola was the primary author, undertook the conceptualization, methodology and prepared the manuscript, Ogunsanwo O.Y supervised and provided the critical revisions of the manuscript and Ige Ayodeji R. assist with the analyses, software and reviewing and editing.

\subsection{Funding}

The authors acknowledge the fund from Tertiary Education Trust Fund Nigeria (TETFUND).

\subsection{Acknowledgements}

The authors would like to thank staff from Department of Forest Products and Production, university of Ibadan and Forestry Research Institute of Nigeria, Ibadan for their support towards the successful completion of this study.

\subsection{Availability of Data and Materials}

The data belongs in full to the authors of this publication which was developed by Dr. Adegoke, Idowu Abimbola of Federal University Gashua, Yobe, State Nigeria. Any request to use the original data for publication purposes requires approval from the authors.

\subsection{References}

[1] F. Hu, and A. Ragauskas, "Pretreatment and lignocellulosic chemistry”, Bioenerg Res., Vol. 5, Pp. 1043-1066, 2012. doi:10.1007/s12155-012-9208-0

[2] M. Tripathi, J.N. Sahu, and P. Ganesan, "Effect of process parameters on production of biochar from biomass waste through pyrolysis: A review", Renewable and Sustainable Energy Reviews, Vol. 55, Pp. 467-481, 2016.

[3] D. Mohan, C.U. Pittman, and P.H. Steele, "Pyrolysis of wood/biomass for bio-oil: A critical review", Energy and Fuels, Vol. 20, Pp. 848-889, 2006.

[4] Q. Lu, Z.F. Zhang, C.Q. Dong, and X.F. Zhu, "Catalytic upgrading of biomass fast pyrolysis vapors with nano metal oxides: An analytical Py-GC/MS study", Energies, Vol. 3, Pp. 1805-1820, 2010.

[5] European Research Centre of Netherland, “Phyllis, database for biomass and waste”, Energy research Centre of the Netherlands, 2005.

[6] C.O. Edmund, L. Zhenglong, K. Shantanu, S. Christopher, and O. Samuel, "Bio-oil yield potential of some tropical woody biomass", Journal of Energy in 
Southern Africa, Vol. 26, No. 2, Pp. 33-41, 2015.

[7] T.B. Onifade, S.O. Wandiga, I.A. Bello, S.O. Jekayinfa, and P.J. Harvey, "Conversion of lignocelluloses from palm (Elaeis guineensis) fruit fibre and physic (Jatropha curcas) nut shell into bio-oil", African Journal of Biotechnology, Vol. 16, No. 46, Pp. 2167-2180, 2017.

[8] A.R. Ige, C.M. Elinge, M. Aliyu, M. Gwani, and L.G. Hassan, "Optimization and characterization of bio-oil produced from rice husk using surface response methodology", Acta Chemica Malaysia, Vol. 5, No. 1, Pp. 10-17, 2020. DOI: 10.2478/acmy-2021-0003.

[9] A.R. Ige, C.M. Elinge, M. Aliyu, M. Gwani, and L.G. Hassan, "Optimization of groundnut shell fast pyrolysis for the production and characterization of biooil using fabricated fixed bed reactor", International Journal of advanced Chemistry, Vol. 8, No. 2, Pp. 217-224, 2020. DOI: 10.14419/ijac.v8i2.31050.

[10] E. Jakab, G. Varhegyi, and O. Faix, "Thermal Decomposition of Polypropylene in the Presence of Wood Derived Materials", Journal of Anal Pyrolysis, Vol. 56, Pp. 273-85, 2000.

[11] B.A. McCarl, C. Peacorke, R. Chrisman, C.C. Kung, and R.D. Sands, "Economics of Biochar Production, Utilization and Greenhouse gas Effects", Biochar for Environment Management Science and Technology: London; Earthscan, Pp. 341-57, 2009.

[12] A. Dermibas, "Progress and recent trends in Biodiesel fuels", Energy conversion and management, Vol. 50, Pp. 14-34, 2009.

[13] D. Khaerbouche, and B. Benyoucef, "Production of Hydrogen from Pyrolysis of Biomass: Influence of Temperature, substrate and catalyst", Journal of E ngineering and Applied Science, Vol. 6, Pp. 91-5, 2011.

[14] P.A. Arevalo, E.G. Baggethun, B.M. Lopez, and M.P. Rincon, "Widening the evaluative space for ecosystem services: A taxonomy of plural values and valuation methods", Environmental values, Vol. 27, No. 1, Pp. $29-53,2018$.

[15] O.Y. Ogunsanwo, and I.A. Adegoke, "Thermo-Chemical Characterization of Bio-Oil Produced from Sawdust of Three Hard Wood Species in Nigeria", Journal of Environmental Extension, Vol. 10, No. 1, 2011.

[16] N.N. Kasim, A.R. Mohamed, M.A.M. Ishak, R. Ahmad, W.I. Nawawi, K. Ismail, and N.H.M. Salleh, "Optimization of pyrolysis process parameters of torrefied demineralized palm empty fruit bunch (TDEFB) by response surface methodology", AIP Publishing, 2018.

[17] ASTM E 872-82, "Standard test method for volatile matter in the analysis of particulate wood fuels, West Conshohocken, (Pennsylvania): ASTM International and Plant Products", Purdue University, USA, 2006.

[18] ASTM D 4052, "Standard test method for density and relative density of liquids by digital density meter", Easton, MD: American Society for Testing and Materials, 1988.

[19] ASTM D 445, "Standard test method for kinematic viscosity of transparent and opaque liquids (and the calculation of dynamic viscosity)", Easton, MD: American Society for Testing and Materials. Book of ASTM Standard, Vol. 05, No. 01, 1988.

[20] ASTM D 482-07, “Standard Test Method for Ash from Petroleum Products", American Society for Testing and Materials, 2007.

[21] ASTM D 5373, "Standard test methods for instrumental determination of carbon, hydrogen, and nitrogen in laboratory samples of coal", American Society for Testing and Materials, USA, 2008.

[22] K. Muthukumarappan, A. Sivasastri, and C. Karunanithy, "Characteriztion of Biochar and Bio-oil Produced from Different Feedstocks", Journal of Agricultural Machinery Science, Vol. 7, No. 4, Pp. 351-354, 2011.

[23] F. Yu, S. Deng, P. Chen, Y. Wan, A. Olson, D. Kittleson, and R. Ruan, "Physical and Chemical Properties of Bio-oils from Microwave Pyrolyis of Corn Stover", Applied Biochemistry and Biotechnology, Vol. 136-140, Pp. 957-970, 2007.

[24] E.A. Antonakou, Lappas, M.H. Nilsen, A. Bouzga, and M. Stocker, "Evaluation of various types of Al-MCM-41 materials as catalysts in biomass pyrolysis for the production of bio-fuel and chemicals", Ibid., Vol. 85, No. 14-15, Pp. 2202-2212, 2006.

[25] H. Aubin, and C. Roy, "Fuel Science Technology International”, Vol. 8, Pp. 77-86, 1980.

[26] A. Oasmaa, and S. Czernik, "Fuel oil quality of biomass pyrolysis oils - state of the art for the end users", Energy and Fuels, Vol. 13, No. 4, Pp. 914-921, 1999.

[27] F. Abnisa, A. Arami-Niya, D. Wan, and J.N. Sahu, "Characterization of Bio-oil and Bio-char from Pyolysis of Palm Oil Wastes", BioEnergy Research, Vol. 6, No. 2, Pp. 830-840, 2013a.

[28] N. Abdullah, and H. Gerhauser, “Bio-oil Derived from Empty Fruit Bunches”, Fuel, Vol. 87, No. 12, Pp. 2606-2613, 2008.

[29] W. Piyarat, and T. Chiyot, "Fuel Properties and ChemicalCompositions of Bio-oils from Biomass Pyrolysis", Journal of Society of Automatic Engineers of Japan; JSAE 2007087,SAE 2007-01-2024.

[30] L.G. Hassan, and N.A. Sani, "Preliminary Studies on Biofuel Properties of Bottle Gourd (Lagenaria siceraria) Seeds Oils", Nigerian Journal of Renewable Energy., Vol. 14, No. 1\&2, Pp. 12-15, 2006.

[31] H.S. Heo, "Fast pyrolysis of rice husk under different reaction conditions", Journal of Industrial and Engineering Chemistry, Vol. 16, Pp. 27-31, 2010.

[32] A.N.E. Rahman, M.A. Khaleel, and K.B.S. Prasad, "Pyrolysis of Solid Wastes", Journal of Scientific and Industrial Research, Vol. 60, Pp. 52-59, 2001. 